\title{
IMPLEMENTASI NILAI TOTAL QUALITY MANAGEMENT DALAM PENGELOLAAN WAKAF DI DOMPET DHUAFA DAN PONDOK PESANTREN TEBUIRENG
}

\author{
Sudirman \\ Fakultas Syariah UIN Maulana Malik Ibrahim Malang \\ Email: sudirmanhasan@yahoo.com
}

\begin{abstract}
Abstrak
This study raises the issue of the implementation of Total Quality Management's values for waqf management. The research aims to investigate the efforts of Dompet Dhuafa and Pondok Pesantren Tebuireng in terms of focus on customers, continuous improvement, and total involvement. The study is a kind of economic research in Islamic law. The data are collected through interview, observation, and documentation. Waqf management carried out by Dompet Dhuafa and Pondok Pesantren Tebuireng are described and analyzed comparatively using Total Quality Management theory as a tool for analysis. The findings of this study are as follows. 1) In the area of focus on customers, Dompet Dhuafa and PP Tebuireng provide sufficient services for customers. 2) In the point of process improvement, Dompet Dhuafa and PP Tebuireng make several efforts to improve their performance. 3) In total involvement, Dompet Dhuafa and PP Tebuireng engage the elements of organizations, including leaders, workers, and partners.

Penelitian ini mengangkat masalah pelaksanaan nilai-nilai Total Quality Management untuk manajemen wakaf. Penelitian ini bertujuan untuk mengetahui upaya Dompet Dhuafa dan Pondok Pesantren Tebuireng dalam hal fokus pada pelanggan, perbaikan terusmenerus, dan keterlibatan total.Penelitian ini merupakan jenis penelitian ekonomi dalam hukum Islam. Data dikumpulkan melalui wawancara, observasi, dan dokumentasi. Waqf manajemen dilakukan oleh Dompet Dhuafa dan Pondok Pesantren Tebuireng diuraikan dan dianalisis relatif menggunakan teori Total Quality Management sebagai alat untuk analisis. Temuan dari penelitian ini adalah sebagai berikut. 1) Dalam bidang fokus pada pelanggan, Dompet Dhuafa dan PP Tebuireng menyediakan layanan yang memadai bagi pelanggan. 2) Dalam hal perbaikan proses, Dompet Dhuafa dan PP Tebuireng membuat beberapa upaya untuk meningkatkan kinerja mereka. 3) Dalam keterlibatan total, Dompet Dhuafa dan PP Tebuireng melibatkan unsur organisasi, termasuk pemimpin, pekerja, dan mitra.
\end{abstract}

Kata Kunci: Total Quality Management, Wakaf Management, Kepuasan Pelanggan.

Konsep wakaf telah mengalami perkembangan yang cukup signifikan terutama sejak disahkannya Undang-Undang Nomor 41 Tahun 2004 tentang Wakaf (dalam tulisan ini disingkat UU Wakaf). Misalnya, benda wakaf tidak lagi hanya didefinisikan dengan tanah yang diwakafkan untuk selama-lamanya (seperti dalam Peraturan Pemerintah Nomor 28 Tahun 1977 atau Kompilasi Hukum Islam), tetapi benda wakaf terbagi menjadi barang bergerak dan tidak bergerak (pasal 16) serta dapat diikrarwakafkan untuk jangka waktu tertentu (pasal 
1). Hal ini menyebabkan pengelolaan wakaf dituntut untuk lebih serius dan profesional. Mubarok $^{1}$, Fanani ${ }^{2}$, dan Sudirman ${ }^{3}$ melaporkan bahwa masyarakat Indonesia semakin sadar tentang wakaf kontemporer, khususnya wakaf produktif dan wakaf uang.

Penelitian ini mengangkat isu tentang manajemen mutu terpadu dalam pengelolaan wakaf. Manajemen mutu terpadu dimaksud adalah terjemahan dari Total Quality Management (dalam tulisan ini disingkat TQM). TQM merupakan salah satu terobosan manajemen yang umumnya dilakukan oleh perusahaan besar, seperti Xerox, IBM Rochester, dan Motorola, dalam rangka meningkatkan kualitas produk yang pada muaranya dapat memuaskan konsumen. ${ }^{4}$ Pada fase berikutnya, TQM banyak dilirik oleh perusahaan penyedia jasa, misalnya FedEx (jasa pengiriman). Oleh karenanya, TQM semakin menjadi sesuatu yang tak terelakkan di era kompetisi global yang kian ketat.

Sayangnya, TQM belum banyak dilakukan oleh lembaga-lembaga filantropi. Hal ini dibuktikan dengan tidak banyaknya lembaga jenis ini yang berniat menerapkan manajemen mutu di lingkungannya, apalagi mendaftarkan diri untuk mendapatkan sertifikat ISO. Dompet Dhuafa bisa dikatakan sebagai salah satu simbol lembaga filantopi Indonesia yang sukses. Dompet Dhuafa dapat maju karena didukung oleh banyak faktor, antara lain keberadaannya di ibukota negara dan dukungan sumber daya manusia yang berkualitas di samping fasilitas yang memadai dan penerapan manajemen modern. Para karyawan yang menjadi ujung tombak manajemen Dompet Dhuafa merupakan orang-orang yang mempunyai tekad pengabdian tinggi untuk kebangkitan umat.

${ }^{1}$ Jaih Mubarok, Wakaf Produktif, (Bandung: Simbiosa Rekatama Media, 2008).

${ }^{2}$ Muhyar Fanani, Berwakaf Tak Harus Kaya, Dinamika Pengelolaan Wakaf Uang di Indonesia, (Semarang: Walisongo Press, 2010).

${ }^{3}$ Sudirman, Wakaf Uang Perspektif Fiqih, Hukum Positif, dan Manajemen, (Malang: UIN Maliki Press, 2011).

${ }^{4}$ Stephen George and Arnorld Weimerskirch, Total Quality Management, Strategies and Techniques Proven at Today's Most Successful Companies, (New York: John Wiley and Sons, Inc., 1998), h. vi-vii.
Berbeda dengan Dompet Dhuafa, fenomena lain dapat ditemukan di PP Tebuireng. Salah satu lembaga pendidikan Islam tertua di Jawa Timur ini (berdiri tahun 1889) telah berhasil mengurus tanah wakafnya dengan baik. Bahkan, hampir seluruh tanah wakaf itu sudah bersertifikat wakaf. ${ }^{5}$ Pengelolaan di bawah satu kendali yang menjadi ciri khas membuat pesantren tersebut terhindar dari sengketa tanah wakaf. Hal ini tentunya layak untuk dicermati secara mendalam.

Lebih lanjut, Dompet Dhuafa dan PP $\mathrm{Te}^{-}$ buireng dipilih sebagai lokasi penelitian. Beberapa persamaan mendasar yang dijadikan alasan untuk mengangkat Dompet Dhuafa dan PP Tebuireng adalah bahwa kedua lembaga tersebut meskipun berbeda jenisnya (dari sisi lokasi dan fokus kegiatan), keduanya mempunyai sejumlah persamaan. Di antaranya adalah dalam hal bentuk kenazhiran, fungsi lembaga, program wakaf produktif, perhatian kepada wakif dan nazhir, adanya program dan evaluasi berkala, dan belum ada sengketa wakaf.

Dompet Dhuafa dan PP Tebuireng diangkat menjadi kasus penelitian ini karena keduanya mempunyai beberapa kegiatan yang sesuai dengan prinsip TQM. Prinsip yang dimaksud adalah fokus kepada pelanggan, perbaikan proses, dan keterlibatan total sebagaimana yang disampaikan Tenner dan DeToro. ${ }^{6}$ Misalnya, Dompet Dhuafa telah melakukan berbagai layanan yang dikhususkan untuk memberikan kepuasan kepada pelanggan eksternal maupun internal. Untuk pelanggan eksternal, Dompet Dhuafa memberikan layanan jemput wakaf, laporan keuangan berkala, dan informasi online. Adapun untuk pelanggan internal, Dompet Dhuafa memberikan kesejahteraan di atas Upah Minimum Regional (UMR), jaminan kesehatan, dan peningkatan mutu karyawan. Di sisi lain,

\footnotetext{
${ }^{5}$ Wawancara dengan Muhsin Ks, Bendahara Yayasan Hasyim Asy'ari Tebuireng, 28 Maret 2011. Hal ini juga pernah disampaikan oleh pernyataan Shalahuddin Wahid, Pemimpin PP Tebuireng, pada tanggal 29 Juni 2009.

${ }^{6}$ Arthur R. Tenner and Irving J. DeToro, Total Quality Management, Three Steps to Continuous Improvement, (Massachusetts: Addison-Wesley Publishing Company, Inc., 1992), h. 32-33.
} 
PP Tebuireng melakukan berbagai terobosan untuk memuaskan pelanggan, baik eksternal maupun internal. Untuk pelanggan eksternal, PP Tebuireng membuat naskah bersejarah yang disebut Surat Bagi Budel Damae Keacoran pada tahun 1947, hanya 3 bulan setelah wakif utama, Hasyim Asy'ari, wafat. Selain itu, PP Tebuireng juga melakukan kunjungan ke keluarga wakif yang masih hidup dan menyelenggarakan doa bersama untuk wakif yang sudah meninggal dunia. Adapun untuk pelanggan internal, khususnya para mandor dan petani, PP Tebuireng memberikan insentif dan gaji yang cukup untuk hidup layak. Oleh sebab itu, dalam penelitian ini kedua lembaga tersebut disoroti lebih detail dalam hal pelaksanaan TQM dengan menggunakan tiga nilai TQM yang ditawarkan Tenner-DeToro. ${ }^{7}$

\section{Metode Penelitian}

Penelitian ini mengangkat lebih dari satu kasus, penelitian ini menurut $\mathrm{Yin}^{8}$ disebut juga penelitian multikasus (multiple case study). Kasus-kasus yang diangkat dalam penelitian ini dimaksudkan untuk mencermati keunikan kasus masing-masing dalam penerapan nilai TQM. Dengan demikian, Dompet Dhuafa dan PP Tebuireng dipaparkan secara mandiri dan detail untuk menjawab rumusan masalah yang telah ditetapkan.

Adapun pendekatan yang digunakan dalam penelitian ini adalah pendekatan manajemen, khususnya pendekatan Total Quality Management (TQM). Dengan demikian, pengelolaan wakaf di Dompet Dhuafa dan PP Tebuireng dicermati secara seksama dari cara pandang manajemen yang dilandasi nilai TQM. TQM dianggap tepat untuk dijadikan pisau analisis karena TQM merupakan salah satu jenis manajemen yang meniscayakan kepuasan pelanggan sebagai tujuan akhir.

Pengumpulan data dalam penelitian ini, sebagaimana dipaparkan oleh Meriam, ${ }^{9}$

\footnotetext{
${ }^{7}$ Arthur R. Tenner and Irving J. De Toro, Total Quality Management, h. 33

${ }^{8}$ Robert K. Yin, Studi Kasus, Desain \& Metode, diterjemahkan oleh M. Djauzi Mudzakir, (Jakarta: Rajawali Press, 2008), h. 55.

${ }^{9}$ Sharan B. Merriam, Qualitative Research, a Guide to
}

meliputi tiga metode utama demi terkumpulnya data yang akurat. Metode-metode yang dimaksud adalah wawancara, observasi, dan dokumentasi.

Data yang terkumpul dianalisis secara komparatif. Pengelolaan wakaf yang dilakukan oleh Dompet Dhuafa dan PP Tebuireng dipaparkan dan dianalisis secara komparatif dengan menggunakan teori Total Quality Management sebagai pisau analisis. Analisis komparatif ini disebut Bogdan dan Biklen ${ }^{10}$ sebagai constant comparative, yakni sebuah analisis yang bersumber dari berbagai sumber data dengan analisis formal di awal penelitian dan baru berakhir menjelang data telah terkumpul semuanya.

\section{Teori Wakaf dan Total Quality Management}

Wakaf secara bahasa berasal dari bahasa Arab, yakni waqafa-yaqifu (وَقَفَ-ِقِفْ yang artinya berhenti ,lawan dari kata istamarra (اسنَتَفَّرَ) Wehr ${ }^{12}$ mengartikan waqafa sebagai to come to a standstill atau to come to stop. Kata wakaf sering disamakan dengan al-tahbis (التَّْبِبْسُ) atau al-tasbil (آلَتَسْبِيْلُ) yang bermakna $a l-h\}$

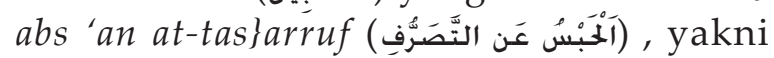
mencegah dari mengelola. ${ }^{13}$ Dalam literatur bahasa Inggris, wakaf biasa disebut sebagai endowment, endowment fund, atau unalienable property. ${ }^{14}$

Adapun secara istilah, wakaf menurut Abu Hanifah dalam al-Hafsaki ${ }^{15}$ adalah

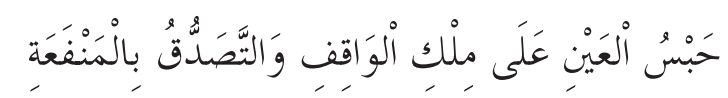

ýakni menahan hárta dí b́awah naungan pemiliknya disertai pemberian manfaat sebagai

Design and Implementation, (San Fransisco: Jossey-Bass, 2009), h. 18.

${ }^{10}$ Robert Bogdan and Sari Knopp Biklen, Qualitative Research for Education: an Introduction to Theory and Methods, (Boston: Allyn and Bacon, 2007), h. 271.

${ }^{11}$ Ahmad Warson, al-Munawwir, Kamus ArabIndonesia, (t.tp.: t.p., 1984), h. 1683.

${ }_{12}$ Hans Wehr, Arabic-English Dictionary, the Hans Wehr Dictionary of Modern Written Arabic, (Urbana: Spoken Language Services, 1994), h. 1280.

${ }^{13}$ Wahbah az-Zuhaili, al-Figh al-Islami wa Adillatuh, (Beirut: Dar al-Fikr, t.th.), h. 7599.

${ }^{14}$ Hans Wehr, Arabic-English Dictionary, h. 1280.

${ }^{15}$ Alauddin Muhammad bin 'Ali al-Hafsaki, ad-Dur al-Mukhtar, (t.tp.: t.p., , t.th.), h. 532. 
sedekah. Menurut al-Kabisi, ${ }^{16}$ definisi yang lebih singkat namun padat (jami` mani') adalah definisi Ibn Qudamah ${ }^{17}$ yang mengadopsi langsung dari potongan hadis Rasulullah, yang berbunyi:

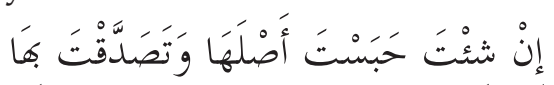

'menahan ásal dan mengalirkan hasilnya' Hadis tersebut secara jelas dimuat antara lain dalam Sunan at-Turmuzi. ${ }^{18}$ Pendapat ini juga menjadi acuan dalam definisi wakaf dalam pandangan Dompet Dhuafa. ${ }^{19}$

Selanjutnya, dalam UU Wakaf pasal 1 angka (1), wakaf diartikan sebagai: perbuatan hukum wakif untuk memisahkan dan/atau menyerahkan sebagian harta benda miliknya untuk dimanfaatkan selamanya atau untukjangka waktu tertentu sesuai dengan kepentingannya guna keperluan ibadah dan/atau kesejahteraan umum menurut syariah.

Dengan pesatnya perkembangan zaman, wakaf tidak lagi hanya diasosiasikan pada obyek wakaf berupa tanah, ${ }^{20}$ akan tetapi sudah merambah kepada wakaf bentuk lain, seperti benda bergerak berupa uang. Di Indonesia, beberapa jenis wakaf baru telah diakomodasi oleh UU Wakaf. Hal ini merupakan bentuk penyempurnaan konsep wakaf yang terdapat dalam Kompilasi Hukum Islam. ${ }^{21}$ Perbedaan mendasar antara definisi UU Wakaf dan KHI adalah bahwa wakaf pada masa kini tidak lagi selalu identik dengan pelembagaan harta yang bersifat abadi namun bisa juga untuk jangka waktu tertentu. Oleh sebab itu, seseorang dapat mewakafkan tanah atau uangnya dalam waktu satu bulan atau satu tahun saja. Ia bisa menarik

\footnotetext{
${ }^{16}$ Muhammad Abid Abdullah al-Kabisi, Hukum Wakaf, diterjemahkan oleh Ahrul Sani Fathurrohman (et.al.), (Jakarta, IIMaN Press, 2004), h. 61.

17 'Abd ar-Rahman bin Abu 'Umar ibn Qudamah, asy-Syarh\} al-Kabir, (t.tp.: t.p., t.th.), h. 187.

${ }_{18}$ Muhłammad bin 'Isa at-Turmuzi, Sunan atTurmuzi, (Kairo: Mauqi' Wizarah al-Auqaf al-Misriyyah, t.th.), h. 388 .

${ }^{19}$ Zaim Saidi, "Kemitraan Investasi Wakaf Produktif," Makalah, (Jakarta: Tabung Wakaf Indonesia, 2007), h. 2 .

${ }^{20}$ Data terakhir per 23 Juli 2009, tanah wakaf di Indonesia berjumlah 2.719.854.759,72 $\mathrm{m} 2$ yang tersebar di 451.305 lokasi (Dokumen dari Departemen Agama, 2009).

${ }^{21}$ Dalam Instruksi Presiden Nomor 1 Tahun 1991 itu, wakaf masih terbatas pada benda tidak bergerak.
}

kembali hartanya itu menjadi hak miliknya secara penuh seperti semula ketika batas waktu yang disepakati telah terlampaui.

Dari beberapa definisi wakaf di atas, dapat disimpulkan bahwa intisari wakaf adalah menjaga dan mengelola pokok harta yang telah diserahkan untuk kepentingan agama dan menyalurkan hasilnya untuk kemaslahatan umat. Wakaf bertujuan untuk memberikan manfaat atau faedah harta yang diwakafkan kepada orang yang berhak dan dipergunakan sesuai dengan ajaran Islam..$^{22} \mathrm{Hal}$ ini sesuai dengan fungsi wakaf yang disebutkan dalam pasal 5 UU Wakaf.

Definisi Total Quality Management bermacammacam. Pengertian TQM yang mudah dicerna dilontarkan oleh $\mathrm{Creech}^{23}$ yang mendefinisikan TQM sebagai "a total approach to put quality in every aspect of management" (sebuah pendekatan menyeluruh untuk meletakkan kualitas di setiap aspek manajemen). Lebih lanjut, Spenley ${ }^{24}$ mengatakan dalam bukunya tentang definisi TQM.

"It is a philosophy of management that strives to make the best use of all available resources and opportunities by constant improvement. Total Quality Management is the key business improvement strategy and the key management issue of the future because it is essential for efficiency and competitiveness....".

Dari dua definisi di atas dapat digarisbawahi bahwa baik Creech maupun Spenley meyakini bahwa TQM merupakan salah satu model manajemen yang mengutamakan peningkatan kualitas demi terciptanya daya saing yang tinggi. Cara yang dilakukan adalah dengan memaksimalkan pemanfaatan potensi dan kesempatan yang dimiliki dengan melakukan perbaikan berkelanjutan. Hal ini senada dengan pendapat Tjiptono dan Diana ${ }^{25}$ yang

${ }^{22}$ Didin Hafidhuddin, Agar Harta Berkah dan Bertambah, (Jakarta: Gema Insani Press, 2007)

${ }^{23}$ Bill Creech, The Five Pillars of TQM, How to Make Total Quality Management Works for You, (New York: The Pinguin Groups, 1994), h. 7.

${ }^{24}$ Paul Spenley, Total Quality Management, the Key to Business Improvement, (London: Chapman \& Hall, 1994), h. 3.

${ }^{25}$ Fandi Tjiptono dan Anastasia Diana, Total Quality Management, (Yogyakarta: Andi, 2003), 120. 
memaknai TQM sebagai "suatu pendekatan dalam menjalankan usaha yang mencoba untuk memaksimalkan daya saing organisasi melalui perbaikan terus-menerus atas produk, jasa, manusia, proses, dan lingkungannya." Dari sini dapat disimpulkan bahwa TQM merupakan sebuah model manajemen yang mengandalkan perbaikan terus-menerus dan pelibatan seluruh elemen organisasi demi tercapainya mutu yang sudah ditetapkan untuk kepuasan pelanggan.

Untuk menerapkan TQM secara praktis, ada baiknya dipaparkan di sini 14 poin manajemen yang dirumuskan Deming ${ }^{26}$ dalam rangka merancang transformasi manajemen yang berkualitas. Deming sebagai salah satu pencetus TQM dalam bukunya Out of the Crisis menulis 14 poin penting untuk menjaga keberlangsungan mutu. Butir-butir tersebut adalah sebagai berikut: (a) Penciptaan tujuan yang mantap ke arah perbaikan barang atau jasa dengan tujuan menjadi lebih kompetitif; (b) Pengadopsian cara berfikir baru, misalnya transformasi manajemen; (c) Penghentian ketergantungan pada inspeksi masal untuk memperoleh kualitas; (d) Penghentian praktik bisnis dengan hanya bergantung pada harga. Hal ini bisa dilakukan dengan membina hubungan jangka panjang dengan pemasok yang berdasarkan kesetiaan dan kepercayaan; (e) Peningkatan perbaikan terus-menerus pada sistem produksi dan pelayanan sehingga dapat meningkatkan kualitas dan menurunkan biaya; (f) Pelembagaan pelatihan kerja; (g) Pelembagaan kepemimpinan; (h) Penghapusan ketakutan sehingga setiap orang dapat bekerja secara efektif; (i) Penghapusan hambatan-hambatan di antara departemen, (j) Penghapusan slogan, desakan, dan target kepada karyawan; (k) Penghapusan kuota produksi kerja dan manajemen serba sasaran; (l) Penghapusan penghalang yang merampas para pekerja dari hak kebanggaan kerja; (m) penghapusan penghalang yang merampok orang-orang yang berada dalam manajemen dan rekayasa dari hak kebanggaan kerja; (n) Pelembagaan

${ }^{26}$ W. Edwards Deming, Out of the Crisis, (Cambridge: MIT Press, 2002), h. 23-24. program pendidikan dan pengembangan diri secara serius; (o) Penggerakan setiap orang untuk mencapai transformasi di atas.

Sedikit berbeda dengan Deming, TennerDeToro $^{27}$ mengemukakan tiga prinsip utama dalam TQM. Ketiga hal tersebut adalah: (a) Fokus kepada pelanggan (focus on customer). Maksudnya adalah perhatian sebuah organisasi atau institusi terhadap pelanggannya baik internal maupun eksternal. Kualitas didasarkan kepada konsep bahwa setiap orang mempunyai pelanggan. Keinginan dan harapan pelanggan harus dipenuhi setiap saat oleh sebuah organisasi. Oleh sebab itu, untuk menentukan keinginan pelanggan, sejumlah analisis harus dilakukan agar tidak salah langkah; (b) Perbaikan proses (process improvement) yang terus-menerus. Konsep peningkatan kualitas secara terus-menerus berawal dari asumsi bahwa sebuah hasil kerja merupakan akumulasi dari serangkaian langkah kerja yang saling terkait hingga muncullah output. Perhatian yang berkelanjutan terhadap setiap langkah dalam proses kerja merupakan satu hal yang harus dilakukan demi mengurangi output yang berbeda-beda dan meningkatkan keterpercayaan proses. Tujuan pertama dari perbaikan yang berkesinambungan adalah proses yang tepercaya dalam artian bahwa output yang dihasilkan setiap waktu akan sama dan sesuai dengan standar yang ditentukan. Apabila variasi output telah diperkecil namun hasilnya belum dapat diterima, tujuan kedua dari perbaikan proses adalah mendesain ulang proses produksi sehingga memperoleh hasil yang lebih baik dan sesuai dengan harapan pelanggan; (c) Keikutsertaan total (total involvement). Pendekatan ini dimulai dengan adanya pemimpin yang aktif dari manajemen senior dan mencakup usaha untuk menggunakan keahlian karyawan dari organisasi tersebut untuk meraih keuntungan persaingan di pasar. Karyawan di setiap jenjang diberi bekal untuk meningkatkan hasil kerja dengan bekerja sama dalam struktur bekerja yang fleksibel dalam penyelesaian masalah, peningkatan proses,

${ }^{27}$ Arthur R. Tenner and Irving J. De Toro, Total Quality Management, h. 33 
dan memberikan kepuasan pada pelanggan. Begitu pula mitra kerja luar harus dilibatkan secara aktif dengan bekerja sama dengan karyawan yang terdidik untuk memberikan keuntungan bagi organisasi.

Dari uraian di atas, penulis cenderung memilih pendapat Tenner-DeToro untuk dijadikan sebagai pisau analisis untuk mencermati pengelolaan wakaf di Dompet Dhuafa dan PP Tebuireng. Pemilihan ini bukan bermaksud merendahkan teori yang lain melainkan demi memudahkan penulis untuk mengalisis data yang terkumpul. Dengan menggunakan ketiga prinsip tersebut, analisis pengelolaan wakaf dirasa lebih mudah dan fokus.

\section{Total Quality Management untuk Wakaf: Pengalaman Dompet Dhuafa dan PP Tebuireng}

Mengingat perlunya manajemen wakaf yang baik sebagaimana sering diungkap para pendukung manajemen filantropi seperti Sudewo, ${ }^{28}$ Tulus dkk, ${ }^{29}$ dan Wadjdy-Mursyid, ${ }^{30}$ penelitian ini mengangkat kasus Dompet Dhuafa dan PP Tebuireng sebagai dua lembaga yang mendapat penilaian sebagai lembaga yang sukses dalam pengelolaannya. Berikut ini dipaparkan sejumlah usaha pengembangan wakaf yang telah dilakukan oleh kedua lembaga tersebut.

\section{Terobosan Dompet Dhuafa dalam Pengelolaan Wakaf}

Dompet Dhuafa lahir tahun 1993 dan awalnya hanya menjaring donasi dari pintu zakat infak dan sedekah. Kemudian, tahun 2001, Dompet Dhuafa mengembangkan diri dengan membuka pintu penjaringan dana wakaf. Dari tahun ke tahun, jumlah wakaf uang yang mereka terima mengalami peningkatan yang cukup tajam. Oleh sebab itu, demi suksesnya pengelolaan aset wakaf tersebut, Dompet Dhuafa mendirikan sebuah jejaring

\footnotetext{
${ }^{28}$ Eri Sudewo, Manajemen Zakat, (Jakarta: Institut Manajemen Zakat, 2004).

${ }^{29}$ Tulus dkk., Nazhir Profesional dan Amanah, (Jakarta: Direktorat Pengembangan Zakat dan Wakaf, 2005).

${ }^{30}$ Farid Wadjdy dan Musyid, Wakaf \& Kesejahteraan Umat (Filantropi Islam yang Hampir Terlupakan), (Yogyakarta: Pustaka Pelajar, 2007).
}

khusus yang fokus untuk menangani wakaf meskipun masih harus berkoordinasi secara intensif dengan Dompet Dhuafa. Lembaga itu bernama Tabung Wakaf Indonesia (TWI) yang berdiri tahun 2005 .

TWI yang merupakan salah satu lembaga baru terus mencari bentuk. Beberapa kali bongkar pasang pengurus termasuk tugas dan kewajibannya sering berubah-ubah seiring dengan perkembangan Dompet Dhuafa. Pada bentuk struktur terbaru, TWI diberi tugas sebagai jejaring Dompet Dhuafa yang berkhidmad untuk mengelola seluruh aset Dompet Dhuafa. Bahkan, dalam sebuah pernyataannya presiden direktur Dompet Dhuafa, Ismail A. Said, TWI ke depan akan menjadi salah satu lembaga yang kaya karena seluruh aset Dompet Dhuafa akan di bawah kendalinya.

Untuk mengukuhkan posisi Dompet Dhuafa sebagai pengelola dana umat yang berkualitas, Dompet Dhuafa berhasil mendapatkan sertifikat ISO. Lembaga ini sudah memulai menata diri sejak tahun 2001 dan baru berhasil memperoleh sertifikat ISO9001:2008 pada awal tahun 2011. Setidaknya dibutuhkan waktu sekitar 10 tahun untuk mewujudkan lembaga yang bermutu. Ini menunjukkan bahwa perbaikan terus-menerus merupakan salah satu kunci keberhasilan sebuah lembaga sebagaimana ditegaskan oleh Sallis ${ }^{31}$ bahwa perbaikan secara terus-menerus merupakan cara tepat untuk mewujudkan TQM. Dengan sertifikat itu, citra Dompet Dhuafa sebagai lembaga pengelola dana umat termasuk wakaf semakin mantap. Kegiatan Dompet Dhuafa selalu didasarkan kepada manual mutu yang telah mereka buat.

Dari uraian di atas dapat diketahui bahwa Dompet Dhuafa telah melakukan pengelolaan secara profesional dengan melandaskan diri pada standar ISO. Meskipun ISO bukan jaminan bahwa sebuah lembaga telah memiliki budaya mutu yang sempurna, namun dengan dimilikinya sertifikat ISO menunjukkan bahwa Dompet Dhuafa telah be-

${ }^{31}$ Edward Sallis, Total Quality Management in Education, diterjemahkan oleh Ahmad Ali Riyadi dan Fahrurrozi, (Yogyakarta: Ircisod, 2010), h. 76. 
rusaha memenuhi kriteria mutu yang menjadi dasar penilaian tim sertifikasi ISO. Dengan ISO, sebagaimana pendapat Sonhadji, ${ }^{32}$ sebuah lembaga sudah berusaha untuk menerapkan TQM di lingkungannya. Dengan demikian, Dompet Dhuafa berpeluang untuk menjadi institusi maju yang siap berkompetisi dalam persaingan global di kemudian hari.

\section{Terobosan PPTebuireng dalam Pengelolaan Wakaf}

Berbeda dengan Dompet Dhuafa, PP Tebuireng telah mengelola wakaf sejak pesantren ini berdiri di akhir abad ke-19, tepatnya tahun 1899. Waktu itu, PP Tebuireng dibangun di atas tanah milik Hasyim Asy'ari yang akhirnya diwakafkan. Wakaf pesantren ini terus berkembang hingga tersebar di 9 lokasi. Di antaranya adalah tanah wakaf di Jombok dan Kwaron yang berbeda kecamatannnya dengan Tebuireng. Penjaminan tanah wakaf pesantren ini sudah dimulai dengan disusunnya Surat Bagi Budel Damae Keacoran di awal kepemimpinan Wahid Hasyim tahun 1947.

Gaya khas pesantren yang diusung PP Tebuireng menjadikan pengelolaan wakaf di pesantren ini nampak unik. Dibandingkan dengan pesantren pada umumnya, PP Tebuireng tergolong sukses dalam mengelola wakaf. Hal ini terbukti dengan semakin berkembangnya aset dan pemanfaatan tanah wakaf yang dimiliki. Dari sisi kuantitas aset wakaf, PP Tebuireng hingga tahun 2011 mempunyai tanah wakaf seluas $43,5 \mathrm{Ha}$. Tidak kurang dari 13 gedung baru dibangun di atas tanah wakaf untuk pengembangan pendidikan dan dana yang digunakan pun mayoritas dari wakaf sejumlah tokoh masyarakat.

Perbandingan Implementasi Nilai TQM dalam Wakaf: Pengalaman Dompet Dhuafa dan PP Tebuireng

\section{Perbandingan Fokus kepada Pelanggan}

Bagian ini memaparkan perbandingan Dompet Dhuafa dan PP Tebuireng dalam

\footnotetext{
${ }^{32}$ Ahmad Sonhadji, K.H., "Penerapan Total Quality Management dan ISO dalam Pendidikan Teknik," Jurnal Ilmu Pendidikan, (Malang: IKIP Malang, 1999), h. 3-10.
}

hal fokus kepada pelanggan dengan menitikberatkan pada keunikan masing-masing. Ini merupakan nilai pertama dalam teori Tenner-DeToro. Berdasarkan pengamatan praktik fokus kepada pelanggan, ditemukan persamaan-persamaan dan juga perbedaanperbedaan pengelolaan wakaf antara Dompet Dhuafa dan PP Tebuireng. Sejumlah persamaan dan perbedaan itu antara lain adalah sebagai berikut.

\section{Definisi Pelanggan}

Saat mengartikan pelanggan, Dompet Dhuafa dan PP Tebuireng sepakat bahwa pelanggan adalah orang-orang yang terlibat baik langsung maupun tidak langsung dalam pengelolaan wakaf. Hal ini dapat dicermati dalam manual mutu Dompet Dhuafa yang mengidentifikasi pelanggan sebagai wakif, mauquf alaih, dan mitra kerja. Adapun PP Tebuireng lebih memberikan makna lebih fleksibel yakni semua pihak yang terlibat dalam pengelolaan wakaf. Dari sini dapat ditangkap persamaannya bahwa Dompet Dhuafa dan PP Tebuireng memberikan apresiasi kepada semua pihak yang terlibat dalam pengelolaan wakaf sebagai pelanggan.

Meskipun begitu, di sisi lain, definisi pelanggan bagi Dompet Dhuafa nampaknya lebih cenderung kepada pelanggan eksternal. Padahal, sebagaimana diungkap oleh Bank ${ }^{33}$ dan Juran, ${ }^{34}$ perhatian kepada pelanggan internal dan ekternal harus imbang dan seiring sejalan untuk mewujudkan TQM. Meskipun begitu, patut dimengerti bahwa tujuan utama fokus kepada pelanggan adalah pelayanan yang prima kepada pelanggan eksternal. Hal ini bukan berarti bahwa pelanggan internal tidak diperlukan. Maksud perhatian lebih kepada pelanggan eksternal adalah bahwa mereka mempunyai peran penentu bagi laku tidaknya produk atau layanan yang diberikan. Misalnya, ketika Dompet Dhuafa meluncurkan program wakaf tunai namun tidak ada donatur yang

\footnotetext{
${ }^{33}$ John Bank, the Essence of Total Quality Management, (Essex: Pearson Education Limited, 2000), h. 26.

${ }^{34}$ J.M. Juran, Juran on Quality by Design, the New Step for Planning Quality into Goods and Services, (New York: The Free Press, 1992), h. 8.
} 
tertarik, maka program itu dengan sendirinya akan gagal dan ditutup. Oleh sebab itu, definisi pelanggan bagi Dompet Dhuafa lebih menekankan kepada konsumen produk yang dibuat ketimbang kepada produsen program.

Hal ini berbeda dengan PP Tebuireng. Lembaga ini memang sejak awal tidak terlalu mempermasalahkan klasifikasi pelanggan. Bagi PP Tebuireng, hal terpenting adalah bagaimana mereka bisa menjaga amanat wakif yang sudah mempercayakan asetnya kepada mereka. Pelanggan dalam artian konsumen wakaf bagi PP Tebuireng sama pentingnya dengan produsen program wakaf. Sebabnya adalah program wakaf di Tebuireng masih terbatas pada wakaf aset atau tanah. Sirkulasi dana dan aset wakaf tidak secepat Dompet Dhuafa sehingga perhatian kepada pelanggan eksternal dianggap sejajar dengan perhatian kepada pelanggan internal. Perhatian secara finansial diberikan kepada pelanggan internal yang benar-benar bekerja seperti mandor dan petani. Adapun perhatian kepada para nazhir, PP Tebuireng belum mengalokasikan dana besar untuk mereka karena tugas dan tanggung jawabnya belum dilaksanakan secara maksimal.

\section{Pelayanan kepada Pelanggan Eksternal}

Dalam hal pelayanan kepada pelanggan eksternal, Dompet Dhuafa dan PP Tebuireng sama-sama fokus kepada wakif. Wakif bagi keduanya adalah sumber aset yang vital. Tanpa wakif, Dompet Dhuafa tidak akan dapat membangun berbagai fasilitas gedung, perkantoran, ruko, dan bahkan rumah sakit untuk dhuafa. Begitu pula bagi PP Tebuireng, tanpa wakif, pesantren ini tidak akan pernah terwujud. PP Tebuireng lahir dari niat ikhlas Hasyim Asy'ari untuk mengembangkan pendidikan Islam dengan rela mewakafkan sebagian besar kekayaannya. Rumah kediamannya menjadi rumah pusaka yang hanya boleh ditinggali oleh pengasuh pesantren. Ketika seorang pengasuh telah wafat, maka keluarganya harus mencari tempat tinggal di luar pesantren karena rumah itu akan didiami oleh pengasuh berikutnya. Dengan demikian, posisi wakif bagi Dompet Dhuafa dan PP Tebuireng memegang peranan penting dalam keberlanjutan wakaf yang mereka kelola.

Persamaan lain antara kedua lembaga itu adalah bahwa kepuasan wakif adalah prioritas utama. Dompet Dhuafa dengan manajemen modernnya membuat manual mutu yang diharapkan mampu memberikan kepuasan bagi wakif. Dompet Dhuafa mempunyai perangkat staf yang bertugas sebagai Customer Relation Management (CRM). Setiap hari, tugas CRM adalah melakukan berbagai pelayanan agar pelanggan merasa dihargai, dihormati, dan diperhatikan kepentingannya. Berbagai upaya CRM dilakukan demi menjalin komunikasi yang baik dengan pelanggan. Majalah Swara Cinta, internet, dan media komunikasi lainnya dimanfaatkan betul untuk tujuan ini. Kunjungan ke rumah wakif juga dianggap langkah jitu untuk membuat wakif merasa dilayani.

Meskipun beda responnya, PP Tebuireng juga melakukan hal serupa. Petugas yang menjadi nazhir wakaf berusaha mengkomunikasikan perkembangan wakaf kepada para wakif. Hingga tahun 2011, wakif yang masih hidup hanya satu orang, yakni Ghazali yang sudah berumur sekitar 80 tahun. Nazhir menunjuk sejumlah pekerja yang mengolah tanah sawah yang mendominasi wakaf di PP Tebuireng. Selain itu, PP Tebuireng memberikan penjelasan kepada para wakif tentang hasil pengelolaan sawah yang mereka wakafkan.

Selain persamaan di atas, ada sejumlah perbedaan antara keduanya. Dompet Dhuafa yang mulai menerima wakaf sejak tahun 2001 telah mempunyai donatur di tahun 2011 tidak kurang dari 3700 orang yang telah mempercayakan milyaran rupiah kepada lembaga ini. Otomatis, pelayanan kepada pelanggan eksternal lebih intensif dan masif ketimbang PP Tebuireng. Segala teknologi digunakan oleh Dompet Dhuafa untuk memudahkan wakif berwakaf dan berkomunikasi. Ini tentunya tidak ditemukan di PP Tebuireng. PP Tebuireng saat ini masih belum mengelola wakaf uang sehingga fokus kepada pelanggan eksternal 
tidak perlu dilakukan setiap hari dengan menunjuk petugas khusus untuk itu. Kantor yang digunakan sebagai markas pengelolaan wakaf pun masih bergabung dengan kantor yayasan. Kenyataan ini tentu saja kurang tepat jika dibanding dengan Dompet Dhuafa yang mempunyai fasilitas kantor khusus untuk wakaf yang lengkap dengan sarana-prasarananya.

Perlu ditekankan di sini bahwa meskipun PP Tebuireng belum semaju dan secanggih Dompet Dhuafa dalam mengelola wakaf, lembaga ini mempunyai kelebihan yang sulit untuk ditandingi oleh Dompet Dhuafa, yakni tradisi mendoakan wakif pada waktu-waktu tertentu. Setiap malam Jumat, sebagai contoh, seluruh santri di PP Tebuireng melakukan tahlilan berjamaah yang antara lain bertujuan untuk mendoakan para wakif, baik yang sudah meninggal maupun yang masih hidup, agar amal ibadah mereka diterima dan hidup bahagia dunia akhirat. Tradisi ini sudah lazim mereka lakukan sebagai tanda terima kasih kepada para wakif, terutama yang berperan serta membesarkan pesantren hingga maju seperti saat ini.

Pada poin ini, jika ditinjau dari nilai TQM versi Tenner-DeToro, Dompet Dhuafa dan PP Tebuireng boleh dikatakan sudah melaksanakan TQM dalam hal fokus kepada pelanggan eksternal. Bentuk perhatian kepada pelanggan jenis ini bisa berbeda tergantung besar-kecilnya lembaga atau banyak-sedikitnya pelanggan. Lembaga seperti Dompet Dhuafa yang mempunyai aset wakaf yang besar dan jumlah wakif yang banyak melakukan pelayanan intensif untuk mereka. Berbeda dengan itu, PP Tebuireng belum perlu menyediakan tenaga khusus setiap hari dalam melayani pelanggan eksternal. Dengan cara tersebut pun pelanggan sudah merasa cukup puas. Hal ini sesuai dengan pernyataan Deming bahwa TQM dapat diterapkan di lembaga kecil atau besar, termasuk lembaga yang tidak berorientasi profit.

\section{Pelayanan kepada Pelanggan Internal}

Pelanggan internal mempunyai posisi penting bagi Dompet Dhuafa dan PP Tebuireng.
Keduanya merupakan tulang punggung pengelolaan wakaf. Bagi Dompet Dhuafa, pelanggan internal meliputi seluruh pimpinan dan karyawan yang bekerja keras membesarkan lembaga. Khusus untuk wakaf, pelanggan internal Dompet Dhuafa adalah para pengelola TWI dari posisi direktur yang mulai 14 Juli 2011 dipegang oleh Urif Budianto hingga karyawan kebersihan. Para pengurus TWI memang tidak bisa berdiri sendiri. Mereka tetap membutuhkan pihak lain dari keluarga besar Dompet Dhuafa. Misalnya, ketika mereka ingin melakukan pelayanan kepada pelanggan internal, mereka harus berkoordinasi dengan staf CRM. Jika tidak, tentu akan terjadi kesimpangsiuran manajemen yang berakibat pada menurunnya kinerja lembaga. Adapun untuk PP Tebuireng, pelanggan internalnya adalah seluruh pengurus Yayasan PP Tebuireng, mulai dari pengasuh hingga para anggota bidang-bidang kegiatan. Dalam hal wakaf, pelanggan internalnya adalah para pengurus Badan Pengelola Wakaf yang diketuai Eddy Yuswan.

Perhatian kepada pelanggan internal untuk Dompet Dhuafa meliputi antara lain kesejahteraan karyawan, jaminan kesehatan, dan peningkatan mutu karyawan. Gaji yang diterima setiap bulan dirasa cukup untuk hidup selama satu bulan. Hal ini disebabkan oleh jumlah penerimaan setiap bulan sudah berada di atas UMR. Jaminan kesehatan cukup mudah bagi Dompet Dhuafa karena Dompet Dhuafa mempunyai lembaga yang bergerak di bidang kesehatan, yakni LKC dan RST.

Adapun untuk PP Tebuireng, kesejahteraan karyawan sudah mendapat perhatian. Namun untuk jaminan kesehatan dan peningkatan mutu karyawan nampaknya belum masuk daftar prioritas. Hal ini karena karyawan tetap PP Tebuireng yang khusus menangani wakaf masih sedikit. Rata-rata pengurus wakaf adalah orang-orang yang sudah mempunyai pekerjaan rutin lain. Misalnya, Muhsin Ks yang ditunjuk sebagai wakil bendahara yayasan sekaligus koordinator wakaf harus melaksanakan tugas sebagai Pembantu Rektor II Universitas Hasyim Asy'ari. Hal serupa juga dialami para pengurus yang lain. Justru, jumlah petugas 
lapangan yang menangani pengelolaan lahan persawahan lebih banyak. Oleh sebab itu, kesejahteraan karyawan, khususnya petugas lapangan, lebih mendapat perhatian dari nazhir PP Tebuireng. Adapun untuk para nadhir sendiri, mereka tidak mendapatkan bagian kecuali sedikit dari pengelolaan wakaf karena mereka secara otomatis sudah mendapat gaji dari yayasan sesuai dengan tugas utamanya. Tiadanya alokasi kesejahteraan bagi nazhir di PP Tebuireng dirasa cukup masuk akal karena mereka hanya bekerja paruh waktu dan tidak kontinyu dalam mengelola wakaf yang masih terbatas pada wakaf tanah.

Dari informasi di atas, dapat disimpulkan bahwa Dompet Dhuafa dan PP Tebuireng telah memberikan pelayanan yang cukup kepada pelanggan internal meskipun tidak seserius pelayanan kepada pelanggan eksternal. Jika dilihat dari pendapat Bank yang mengatakan bahwa pelanggan internal dan eksternal harus diberi perhatian seimbang, maka Dompet Dhuafa dan PP Tebuireng masih belum dikatakan sepenuhnya melakukan TQM. Pembedaan layanan pelanggan yang cukup berbeda antara pelanggan eksternal dan internal seharusnya tidak boleh terjadi. Kalaupun harus terjadi, layanan pelanggan internal seharusnya tidak terlalu jauh dibandingkan layanan kepada pelanggan eksternal. Hal ini disebabkan oleh alasan bahwa tanpa pelanggan internal yang bekerja keras, layanan yang baik untuk pelanggan eksternal tidak akan pernah terjadi. Dengan demikian, dalam implementasi TQM, kedudukan pelanggan internal harus sama dengan kedudukan pelanggan eksternal.

\section{Perbandingan Perbaikan Proses}

Secara umum, Dompet Dhuafa dan PP Tebuireng telah melakukan sejumlah terobosan untuk melakukan perbaikan proses sebagaimana nilai TQM yang kedua versi Tenner-DeToro. Di antaranya adalah perluasan dan pemeliharaan aset, transparansi dana, dan perbaikan kinerja.

\section{Perluasan dan Pemeliharaan Aset}

Baik Dompet Dhuafa maupun PP Tebuireng telah melakukan berbagai upaya untuk meningkatkan jumlah aset wakaf. Dompet Dhuafa yang lebih fokus kepada wakaf uang setiap tahunnya berhasil mengumpulkan dana wakaf yang jumlahnya bisa mencapai milyaran rupiah, terlebih saat ini sedang membangun Rumah Sehat Terpadu yang sangat modern. Bangunan fasilitas kesehatan untuk dhuafa itu per-Juni 2011 sudah berhasil mengumpulkan dana sebesar Rp 39.000.000.000,--. Ini sebuah bukti bahwa Dompet Dhuafa telah dipercaya sebagai lembaga yang kompeten mengelola wakaf. Demi pengelolaan yang lebih profesional, Dompet Dhuafa mendirikan Tabung Wakaf Indonesia yang bertugas khusus menangani aset wakaf Dompet Dhuafa.

Di sisi lain, PP Tebuireng telah berhasil mensertifikatkan tanah wakaf serta memproduktifkannya. Dibuatnya Surat Budel Damae Keancoran adalah salah satu penguat argumentasi bahwa wakaf di Tebuireng sudah mendapat perhatian serius dari keluarga besar pendiri PP Tebuireng. Hal itu dilanjutkan dengan sertifikasi tanah wakaf yang jumlahnya puluhan hektar. Ini adalah langkah maju PP Tebuireng di saat banyak tanah wakaf milik pondok pesantren lain yang tidak jelas statusnya. Kebijakan untuk tidak memperkenankan ahli waris atau tenaga pengajar pondok mendirikan bangunan rumah di area tanah wakaf rupanya cukup efektif untuk menghindari penggunaan tanah wakaf untuk kepentingan pribadi.

\section{Transparansi Dana}

Dalam hal transparansi keuangan, Dompet Dhuafa mempunyai sistem keuangan yang terbuka dan mudah diakses. Laporan keuangan setiap bulan yang selalu dicantumkan dalam majalah Swara Cinta dan termuat di situs Dompet Dhuafa cukup memudahkan bagi wakif untuk mendapatkan kepastian penggunaan dana mereka. Tim audit internal dan eksternal memperkuat akurasi dan transparansi dana dan aset wakaf yang dikelola Dompet Dhuafa beserta TWI. 
Berbeda dengan itu, PP Tebuireng tidak memiliki fasilitas khusus untuk mempublikasikan arus keuangan pengelolaan wakaf. Sebagaimana beberapa kali disampaikan di beberapa tempat dalam tulisan ini, wakaf yang dikelola PP Tebuireng adalah wakaf tidak bergerak berupa tanah yang tidak membutuhkan penanganan yang rumit. Manajemen wakafnya pun masih menyatu dengan manajemen pesantren. Meskipun begitu, bukan berarti laporan keuangan wakaf di PP Tebuireng tidak ada. Informasi tersebut dapat diakses langsung di bagian keuangan pesantren. Mereka dengan senang hati menyampaikan laporan keuangan secara rinci. Jika urusan tranparansi dana di Dompet Dhuafa dilengkapi dengan auditor eksternal independen, urusan tranparansi dana di PP Tebuireng cukup ditangani oleh auditor internal yang terdiri dari pengawas dan bagian keuangan.

\section{Perbaikan Kinerja}

Untuk hal ini, Dompet Dhuafa telah memiliki manual mutu yang dijadikan sebagai pedoman beraktifitas. Lembaga ini sudah membuat ukuran tertentu sebagai indikator keberhasilan kinerja mereka. Berbeda dengan hal itu, PP Tebuireng belum membuat manual mutu untuk pedoman kinerja mereka. Mungkin, hal ini memang belum diperlukan untuk pengelolaan wakaf di lembaga ini karena aktifitas pengelolaan wakaf tidak diformat secara kaku. Walaupun begitu, PP Tebuireng berkomitmen untuk mengembangkan wakaf secara profesional dengan manajemen yang lebih pasti. Ketika nanti PP Tebuireng mengembangkan program wakaf uang, niscaya sistem penjaminan mutu seperti yang sudah dilaksanakan Dompet Dhuafa akan dirancang.

Lembaga yang sudah menerapkan sistem kerja profesional dalam bidang pengelolaan dana umat di PP Tebuireng adalah Lembaga Sosial Pesantren Tebuireng (LSPT). Lembaga ini merupakan lembaga independen di bawah naungan yayasan yang bertugas mengelola dan menyalurkan dana zakat, infak, dan sedekah. Dana LSPT paling besar bersumber dari kotak amal para peziarah makam Gus Dur yang jumlahnya berkisar antara Rp 15.000.000 25.000.000,- setiap bulannya. Pernah dalam satu bulan, jumlah uang dalam kotak-kotak amal itu mencapai Rp 70.000.000,-. Dana tersebut belum dimanfaatkan untuk kegiatan produktif. Program unggulan yang sekarang sedang mereka garap adalah program beasiswa santri, yatim piatu, dan santunan untuk guru.

Dilihat dari sisi implementasi TQM, pada poin ini Dompet Dhuafa dan PP Tebuireng telah melakukan perbaikan proses. Perbaikan proses seperti dikatakan oleh Tenner-DeToro memang harus dilakukan secara terus-menerus. Tujuan utama perbaikan proses ini adalah untuk memberikan standar mutu yang stabil dan menjadi acuan dalam merancang program baru. Dalam kasus Dompet Dhuafa, perbaikan proses mulai serius dilakukan sejak tahun 2001 ketika lembaga ini ingin mengajukan permohonan sertifikat ISO. Dengan kesungguhan dan kerja keras, akhirnya Dompet Dhuafa berhasil memperoleh sertifikat ISO secara lengkap di awal tahun 2011. Di sisi lain, PP Tebuireng juga telah melakukan perbaikan proses dengan melakukan antara lain penjaminan aset wakaf agar tidak hilang dengan sistem sertifikasi tanah wakaf. Sebelum itu, Surat Bagi Budel Damae Keacoran tahun 1947 menjadi bukti kehati-hatian pengelola wakaf PP Tebuireng dalam memperbaiki sistem penjaminan aset wakaf.

\section{Perbandingan Keterlibatan Total}

Perbandingan keterlibatan total di Dompet Dhuafa dan PP Tebuireng dapat diuraikan sebagai berikut.

\section{Kepemimpinan}

Keterlibatan pimpinan, baik di Dompet Dhuafa maupun di PP Tebuireng, cukup besar. Mereka memanfaatkan posisi terhormat mereka untuk menjalin komunikasi dengan pihak lain yang potensial memberikan dana wakafnya. Meskipun dengan gaya kepemimpinan yang berbeda, pemimpin lembaga Dompet Dhuafa dan PP Tebuireng telah dapat melaksanakan 
peran mereka secara efektif dalam pengelolaan wakaf.

\section{Loyalitas Karyawan}

Kalau loyalitas karyawan di Dompet Dhuafa lebih cenderung dipengaruhi oleh kesejahteraan yang mereka terima, tidak seperti halnya di PP Tebuireng. Tradisi pesantren yang mengagungkan kiai membuat karyawan yang bekerja untuk pesantren tidak terlalu mempedulikan kesejahteraan mereka. Mereka hanya menerima gaji dengan standar yang dibuat pesantren tanpa ada penolakan atau bantahan. Sikap mereka seperti ini disebabkan adanya harapan lain di luar materi, yakni keberkahan dan doa dari para kiai dan santri.

\section{Keterlibatan Mitra Kerja}

Mitra kerja di Dompet Dhuafa dan PP Tebuireng adalah salah satu ujung tombak keberhasilan program yang mereka buat. Tanpa mereka, program wakaf produktif TWI yang mengharuskan keterlibatan mitra kerja seperti pedagang di ruko-ruko tidak akan berhasil. Oleh sebab itu, kerjasama yang baik antara pemilik aset wakaf dengan pengelola wakaf di lapangan tetap menjadi perhatian penting.

Begitu pula dalam kasus pengelolaan lahan pertanian PP Tebuireng, peran mitra kerja yang dalam hal ini para petani menjadi penentu keberhasilan usaha pemberdayaan aset wakaf. Para nazhir atau pengurus wakaf tidak akan mungkin atau setidaknya cukup sulit untuk mengelola langsung aset wakaf. Oleh karena itu, keterlibatan total mitra kerja menjadi suatu keniscayaan demi mewujudkan TQM dalam wakaf.

Pada nilai keterlibatan total yang merupakan nilai TQM ketiga menurut TennerDeToro, Dompet Dhuafa dan PP Tebuireng sama-sama sudah melibatkan berbagai elemen lembaga dari pimpinan hingga mitra kerja untuk mendukung pengelolaan wakaf yang baik. Meskipun begitu, keterlibatan elemen lembaga Dompet Dhuafa lebih banyak dan dinamis ketimbang PP Tebuireng. Hal ini disebabkan oleh situasi pengelolaan wakaf yang memang berbeda. Jika Dompet Dhuafa mengelola wakaf sebagai aktifitas harian dengan TWI sebagai ujung tombaknya, tidak demikian halnya PP Tebuireng. Pengelolaan wakaf khususnya wakaf tanah di PP Tebuireng merupakan aktifitas sampingan yang bisa dikerjakan sebagai tambahan tugas kecuali para mitra kerja yang harus mengelola tanah sawah dalam periode tertentu. Pimpinan atau pengelola wakaf PP Tebuireng nampaknya belum mencurahkan sekuat tenaga untuk mengembangkan aset wakaf.

Dari perbandingan tiga unsur utama TQM berdasarkan teori Tenner-DeToro, dapat disimpulkan bahwa Dompet Dhuafa dan PP Tebuireng memiliki kepedulian dan perhatian yang cukup kepada pelanggan, perbaikan proses, dan pelibatan total pengelola. Meskipun begitu, tidak dipungkiri bahwa Dompet Dhuafa dalam beberapa faktor memiliki keunggulan dan PP Tebuireng juga unggul pada faktor yang lain. Misalnya, Dompet Dhuafa memiliki prosedur mutu yang jelas dan standar pelayanan yang terstruktur. Setiap wakif mendapatkan perhatian yang seimbang karena petugas yang bertanggung jawab akan memberikan pelayanan yang memang sudah ditentukan sebelumnya, seperti pengiriman majalah dan bukti pembayaran. Di sisi lain, PP Tebuireng memiliki kekuatan loyalitas karyawan yang solid. Mereka bekerja sesuai tugas masingmasing namun tidak selalu beroreintasi kepada gaji yang mereka terima. Semangat pengabdian kepada pesantren menjadi salah satu spirit yang perlu dipertahankan demi tercapainya kepuasan wakif. Dari sini dapat disimpulkan bahwa TQM sudah ada di Dompet Dhuafa dan PP Tebuireng dengan variasi implementasi yang berbeda. Hal ini menurut Deming adalah sah-sah saja karena TQM tidak memiliki format yang kaku dan bisa diterapkan di berbagai lembaga, baik besar dan kecil, dengan catatan lembaga tersebut telah menjadikan pelanggan sebagai fokus dalam kegiatan mereka. Dengan semangat nilai TQM yang sudah dilakukan, lambat laun lembaga tersebut akan mempunyai budaya mutu yang sudah menyatu dengan kehidupan 
seluruh elemen lembaga. Setiap orang dapat bekerja dengan senang hati untuk mewujudkan pekerjaan yang bermutu tanpa paksaan dari pihak-pihak di luar diri mereka.

\section{Manajemen Mutu: Sebuah Tawaran untuk Pengelolaan Wakaf}

Berdasarkan hasil penelitian tentang pengelolaan wakaf di Dompet Dhuafa dan PP Tebuireng yang sudah dijabarkan, terdapat sebuah kesimpulan penting bahwa implementasi nilai TQM pada dasarnya tidak selalu dalam bentuk yang sempurna. Ada sebagian lembaga yang unggul pada sisi tertentu dan lemah pada sisi yang lain. Misalnya, dalam hal fasilitas modern, Dompet Dhuafa tergolong unggul. Kelebihan ini kemudian menjadikan Dompet Dhuafa dapat berkiprah lebih luwes dan matang. Meskipun begitu, PP Tebuireng yang unggul dalam penjagaan aset dan pelibatan santri yang loyal menjadikan pengelolaan wakaf tetap eksis dan terjaga. Dari sini dapat dilihat bahwa implementasi TQM dapat disesuaikan dengan keunggulan lokal yang dimiliki tiap-tiap lembaga selama tujuan utama dalam manajemen mereka adalah memberikan kepuasan kepada pelanggan dan berkomitmen untuk terus-menerus melakukan perbaikan serta melibatkan banyak pihak yang terkait. Intensitas masing-masing bisa berbeda-beda. Dengan demikian, cukup meyakinkan bahwa untuk pengelolaan wakaf yang sukses, ketiga unsur ini bisa dijadikan sebagai pilar utama penegak terciptanya budaya mutu dalam pengelolaan wakaf.

Secara ringkas, hasil penelitian ini dapat digambarkan dalam diagram berikut.

Diagram

TQM untuk Wakaf

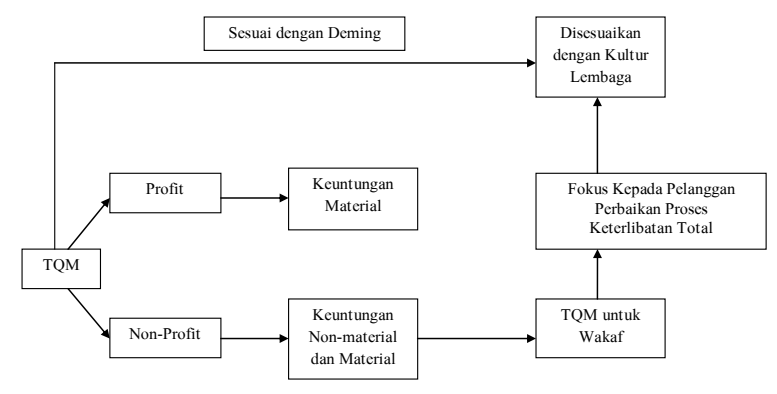

Diagram di atas menunjukkan bahwa TQM pada dasarnya digunakan untuk perusahaan yang berorientasi pada profit. Mereka menerapkan TQMdemi meraup keuntungan material. Namun, di sisi lain, TQM dapat juga diterapkan dalam lembaga yang tidak menjadikan keuntungan material sebagai tujuan utama sebagaimana penelitian Crocker ${ }^{35}$ tentang lembaga agama yang bermutu. Mereka biasa disebut sebagai lembaga non-profit. Pada lembaga jenis ini, penerapan TQM dapat memberikan keuntungan non-material, seperti kepercayaan masyarakat yang meningkat dan penghormatan yang makin tinggi. Dalam kasus wakaf, pengelola yang memiliki beberapa nilai TQM cenderung mampu memberikan kepuasan kepada pelanggannya, dalam hal ini wakif, sehingga pelanggan wakaf puas dengan layanan wakaf yang diberikan. Ketika kepercayaan wakif kepada nazhir meningkat, wakif dapat melakukan promosi kepada kawan-kawannya yang ingin berwakaf. Selain itu, wakif juga bisa melakukan wakaf untuk yang kedua kalinya. Apabila lembaga wakaf sudah dikenal amanah dan profesional, keuntungan materi pun dapat mereka peroleh. Di antara caranya adalah dengan mengelola aset wakaf secara produktif sehingga mereka layak mendapat bagian 10\% dari hasil bersihnya. Dari poin ini, TQM layak diterapkan dalam pengelolaan wakaf.

Lebih lanjut, untuk menerapkan TQM, berdasarkan hasil penelitian ini, tiga nilai TQM patut untuk diperhatikan. Ketiga nilai itu adalah fokus kepada pelanggan, perbaikan proses, dan keterlibatan total. Dari pengalaman Dompet Dhuafa dan PP Tebuireng, dapat disimpulkan bahwa ketiga nilai TQM tersebut telah mereka miliki meskipun dengan kadar yang berbeda. Oleh sebab itu, penerapan TQM dapat disesuaikan dengan situasi dan kultur lembaga masing-masing. Hal ini sejalan dengan pemikiran Deming yang mengatakan bahwa TQM dapat diterapkan dalam lembaga kecil maupun besar. Penelitian ini menambahkan poin penting bahwa TQM dapat diterapkan

${ }^{35}$ Gustavo Crocker, "Total Quality in Charitable Services: Profile of Excellence in Christian Relief and Development Organizations," Disertasi, (Columbia: Regent University, 2001). 
dalam lembaga kecil maupun besar, baik berorientasi profit mapun non-profit. Pada lembaga non-profit, keuntungan yang diperoleh adalah keuntungan non-material sekaligus material.

Secara teoritik, akhirnya dapat disimpulkan bahwa pengelolaan wakaf dengan ukuran prinsip TQM versi Tenner-Detoro dikatakan dapat membuat wakaf berkembang dan terjaga. Kasus Dompet Dhuafa dan PP Tebuireng yang menjadi topik utama penelitian ini menunjukkan hasil yang menggembirakan dalam pengelolaan wakaf mereka. Dengan demikian, tidak diragukan lagi bahwa penerapan TQM dalam wakaf perlu untuk dibudayakan sehingga masalah manajemen yang menjadi persoalan utama pengelolaan wakaf dapat diatasi secara bertahap. Adapun untuk mendapatkan ISO sebagai bukti formal terimplementasinya TQM, sebuah lembaga pengelola wakaf harus bekerja keras untuk memenuhi standar yang sudah ditentukan. Budaya TQM yang sudah terintegrasi dalam perilaku lembaga nampaknya akan memudahkan lembaga tersebut mendapatkan sertifikat ISO.

\section{Kesimpulan}

Dari uraian yang telah disampaikan, pada bagian ini dipaparkan beberapa poin kesimpulan yang disusun berdasarkan permasalahan yang telah dirumuskan: (1) Dalam hal fokus kepada pelanggan, Dompet Dhuafa dan PP Tebuireng memberikan pelayanan yang baik kepada pelanggan. Dari makna pelanggan yang mereka buat, Dompet Dhuafa cenderung mengartikan pelanggan sebagai pelanggan eksternal meskipun dalam praktiknya mereka juga memberikan perhatian yang cukup kepada pelanggan internal. Di sisi yang lain, PP Tebuireng mengartikan pelanggan sebagai pelanggan internal maupun eksternal dengan pelayanan khas pesantren; (2) Untuk perbaikan proses, Dompet Dhuafa dan PP Tebuireng sama-sama melakukan sejumlah kegiatan dan terobosan yang berorientasi kepada perbaikan. Dompet Dhuafa mengukuhkan diri dalam hal perbaikan proses dengan dibuatnya manual mutu. Manual ini disusun dalam rangka mewujudkan standar ISO 9001:2008. Dompet
Dhuafa mendapatkan sertifikat ISO secara lengkap untuk program, fundrising, dan keuangannya di awal 2011. Selain itu, Dompet Dhuafa telah mendirikan jejaring khusus yang menangani wakaf, yakni TWI sejak tahun 2005, yang diproyeksikan akan menjadi institusi yang mengurus seluruh aset wakaf Dompet Dhuafa, baik aset wakaf tetap maupun aset wakaf lancar. Adapun PP Tebuireng telah melakukan perbaikan proses dengan dibuatnya Surat Budel Damae Keancoran di tahun 1947. Perbaikan berikutnya terjadi dengan dibuatnya sertifikat wakaf untuk seluruh aset wakaf pesantren yang luasnya sekitar 43,5 ha. Perbaikan proses yang lain dapat dilihat pada pengembangan pendidikan yang beragam, mulai tingkat SLTP hingga perguruan tinggi. Semua fasilitas pendidikan itu didirikan di atas tanah wakaf; (3) Dalam hal keterlibatan total, Dompet Dhuafa dan PP Tebuireng melibatkan seluruh elemen lembaga, mulai dari pimpinan, karyawan, hingga mitra kerja. Dompet Dhuafa dan PP Tebuireng melibatkan pimpinan dalam penjaringan wakaf di kalangan pejabat dan pengusaha. Adapun untuk karyawan, keterlibatan total yang mereka tunjukkan adalah dalam bentuk loyalitas kepada lembaga. Untuk menjaga loyalitas karyawan, Dompet Dhuafa berusaha memberikan kesejahteraan yang layak sedangkan PP Tebuireng tidak harus memberikan kesejahteraan material demi meraih loyalitas karyawan. Kultur pesantren yang mengagungkan kiai membuat para karyawan pengelola wakaf PP Tebuireng tidak menuntut penghargaan material ketika bekerja untuk pesantren. Mereka sudah cukup puas ketika dapat mengabdikan diri untuk kepentingan pesantren dengan berharap mendapat berkah dari kiai. Adapun untuk keterlibatan mitra, Dompet Dhuafa berusaha memberikan hakhak mitra kerja yang terdiri dari fasilitas yang memadai dan bagi hasil yang seimbang. Adapun PP Tebuireng melibatkan mitra kerja, yakni para petani, untuk mengelola aset wakaf berupa area pertanian dan mitra kerja yang lain, yakni para tenaga pendidik, untuk mengembangkan lembaga pendidikan.

Kemudian, sebagai implikasi teoritiknya, TQM yang semula diperuntukkan bagi lembaga yang berorientasi kepada keuntungan material, ternyata dalam kenyataannya, TQM 
dapat pula diterapkan dalam lembaga yang tidak berorientasi profit. Salah satunya adalah lembaga wakaf. Ketika lembaga wakaf menerapkan nilai TQM baik sengaja maupun tidak, seperti ditunjukkan dalam hasil penelitian di Dompet Dhuafa dan PP Tebuireng, besar kemungkinan lembaga tersebut akan dapat

\section{DAFTAR PUSTAKA}

Abdullah, M. Amin (dkk). Metodologi Penelitian Agama, Pendekatan Multidisipliner. Yogyakarta: Lembaga Penelitian UIN Sunan Kalijaga, 2006.

Bank, John. the Essence of Total Quality Management. Essex: Pearson Education Limited, 2000.

Bisri, Cik Hasan. Pilar-Pilar Penelitian Hukum Islam dan Pranata Sosial. Jakarta: PT. Raja Grafindo Persada, 2004.

Bogdan, Robert, and Sari Knopp Biklen. Qualitative Research for Education: an Introduction to Theory and Methods. Boston: Allyn and Bacon, 2007.

Connolly, Peter. Approaches to the Study of Religion. New York: Cassell, 1999.

Creech, Bill. The Five Pillars of TQM, How to Make Total Quality Management Works for You. New York: The Pinguin Groups, 1994.

Crocker, Gustavo. “Total Quality in Charitable Services: Profile of Excellence in Christian Relief and Development Organizations." Disertasi, Columbia: Regent University, 2001.

Deming, W. Edwards. Out of the Crisis. Cambridge: MIT Press, 2002.

Fanani, Muhyar. Berwakaf Tak Harus Kaya, Dinamika Pengelolaan Wakaf Uang di Indonesia. Semarang: Walisongo Press, 2010.

George, Stephen, and Arnorld Weimerskirch. Total Quality Management, Strategies and Techniques Proven at Today's Most Successful Companies. New York: John Wiley and Sons, Inc, 1998.

Hafidhuddin, Didin. Agar Harta Berkah dan Bertambah. Jakarta: Gema Insani Press, bertahan hidup dan bahkan berkembang pesat dalam melayani masyarakat. Penerapan nilai TQM ini juga dapat disesuaikan dengan kultur lembaga masing-masing. Dengan demikian, pendapat Deming dan hasil penelitian Crocker dikuatkan oleh penelitian ini.

Jakarta, 2007.

al-Hafsaki, Alauddin Muhammad bin 'Ali, t.th., ad-Dur al-Mukhtar, t.tp.: t.p.

Juran, J.M. Juran on Quality by Design, the New Step for Planning Quality into Goods and Services. New York: The Free Press, 1992.

al-Kabisi, Muhammad Abid Abdullah. Hukum Wakaf. Terj. Ahrul Sani Fathurrohman (et.al.), Jakarta, IIMaN Press, 2004.

Merriam, Sharan B. Qualitative Research, a Guide to Design and Implementation. San Fransisco: Jossey-Bass, 2009.

Mubarok, Jaih, Wakaf Produktif, Bandung: Simbiosa Rekatama Media, 2008.

ibn Qudamah, 'Abd ar-Rahman bin Abu 'Umar, t.th., asy-Syarh al-Kabir, t.tp.: t.p.

Saidi, Zaim, "Kemitraan Investasi Wakaf Produktif," Makalah, Jakarta: Tabung Wakaf Indonesia.

Sallis, Edward, Total Quality Management in Education, diterjemahkan oleh Ahmad Ali Riyadi dan Fahrurrozi, Yogyakarta: Ircisod, 2010.

Sonhadji, K.H., Ahmad, "Penerapan Total Quality Management dan ISO dalam Pendidikan Teknik," Jurnal Ilmu Pendidikan, Malang: IKIP Malang, 1999.

Spenley, Paul, Total Quality Management, the Key to Business Improvement, London: Chapman \& Hall, 1994.

Sudewo, Eri, Manajemen Zakat, Jakarta: Institut Manajemen Zakat, 2004.

Sudirman, Wakaf Uang Perspektif Fiqih, Hukum Positif, dan Manajemen, Malang: UIN Maliki Press, 2011.

Tenner, Arthur R., and Irving J. DeToro, Total 
186 I de Jure, Jurnal Syariah dan Hukum, Volume 4 Nomor 2, Desember 2012, hlm. 171-186

Quality Management, Three Steps to Continuous Improvement, Massachusetts: AddisonWesley Publishing Company, Inc, 1992.

Tjiptono, Fandi, dan Anastasia Diana, Total Quality Management, Yogyakarta: Andi, 2003.

Tulus dkk., Nazhir Profesional dan Amanah, Jakarta: Direktorat Pengembangan Zakat dan Wakaf, 2005.

at-Turmuzi, Muhammad bin 'Isa, t.th., Sunan at-Turmuzi, Kairo: Mauqi' Wizarah alAuqaf al-Misriyyah.

Wadjdy, Farid, dan Musyid, Wakaf E Kesejahteraan Umat (Filantropi Islam yang Hampir
Terlupakan), Yogyakarta: Pustaka Pelajar, 2007.

Warson, Ahmad, al-Munawwir, Kamus ArabIndonesia, t.tp.: t.p, 1984.

Wehr, Hans, Arabic-English Dictionary, the Hans Wehr Dictionary of Modern Written Arabic, Urbana: Spoken Language Services, 1994.

Yin, Robert K., Studi Kasus, Desain \& Metode, diterjemahkan oleh M. Djauzi Mudzakir, Jakarta: Rajawali Press, 2008.

az-Zuhaili, Wahbah, t.th., al-Figh al-Islami wa Adillatuh, Beirut: Dar al-Fikr. 